\title{
DEFORESTATION IN MIXED OMBROPHILOUS FOREST IN THE SERRANA REGION OF SANTA CATARINA ${ }^{1}$
}

\author{
Luiz Cláudio Araujo Schneider ${ }^{2 *}$, Morgana Tramontini da Silva ${ }^{3}$, Lenita Agostinetto ${ }^{2}$ and Ana Emilia \\ Siegloch $^{2}$
}

\footnotetext{
${ }^{1}$ Received on 13.06.2017 accepted for publication on 30.01.2018.

${ }^{2}$ Universidade do Planalto Catarinense, Programa de Pós-Graduação em Ambiente e Saúde, Lages, SC- Brasil. E-mail: $<$ luiz.schneider@hotmail.com>,<leagostinetto@yahoo.com.br>and <asiegloch@gmail.com>.

${ }^{3}$ Universidade de Santa Catarina, Programa de Pós-Graduação em Engenharia Florestal, Lages, SC - Brasil. E-mail: $<$ morganatramontini@gmail.com>.

*Corresponding author.
}

\begin{abstract}
Since the enactment of Law No. 11,428/06, an expectation was created as to whether more restricted rules on the use and conservation of the Atlantic Forest Biome would be sufficient to reduce deforestation. In the same sense, the inspection bodies stood out due to their responsibility in the application of this important legal instrument. In this context, the objectives of this study were: 1) to analyze the history of deforestation in the Planalto Serrano of the State of Santa Catarina, whose forest covered area is characterized by the Mixed Ombrophilous Forest, after the validity of Law 11,428/06; 2) to verify the application of the Law in the occurrence of deforestation, and 3 ) to identify the reasons for deforestation. A documentary research was carried out on 543 criminal procedures instituted by the Environmental Military Police for deforestation between December 2006 and December 2015. From each criminal case the following data were extracted: date, number of occurrences per year and municipality, size, successional stage of the deforested area, motive and land use of deforested areas. The results indicated that there was an accentuated reduction of $58 \%$ in the number of deforestation between 2007 and 2015. However, the selective cutting of Araucaria angustifolia (Bertol.) Kuntze was predominant with a percentage of $62.07 \%$ of the total number of occurrences. It was also verified that $71.46 \%$ of deforestation reached the middle stage of forest regeneration. In most case (33\%), the reason for deforestation was for commercial purposes. The law for the protection of the Atlantic Forest Biome, conjunctly with the inspection, contributed to reduce deforestation and the cut of araucarias. Nevertheless, advancements are still needed, especially in the recovery of deforested areas, since only $28 \%$ of deforested areas were effectively restored.
\end{abstract}

Keywords: Atlantic Forest Biome; Inspection; Environmental infractions.

\section{DESMATAMENTO EM FLORESTA OMBRÓFILA MISTA NA REGIÃO SERRANA DE SANTA CATARINA}

\begin{abstract}
RESUMO - A partir da vigência da Lei $n^{\circ} 11.428 / 06$ criou-se uma expectativa se regras mais restritas de uso e conservação da Mata Atlântica seriam suficientes para a redução dos desmatamentos. Na mesma ótica, os órgãos de fiscalização ficaram em evidencia, cobrando-se a aplicação desse instrumento legal. Os objetivos deste estudo foram: 1) analisar o histórico de desmatamento no Planalto Serrano do Estado de Santa Catarina, cuja cobertura florestal é caracterizada por Floresta Ombrófila Mista, após a Lei 11.428/06; 2) verificar a aplicação da Lei nas ocorrências de desmatamento, e 3) identificar os motivos que ocasionaram os desmatamentos. Foi realizada pesquisa documental em 543 procedimentos criminais instaurados pela Polícia Militar Ambiental por desmatamento entre dezembro de 2006 e dezembro de 2015. Em cada processo criminal foram extraídos os seguintes dados: data, número de ocorrência por ano e município, tamanho, estágio sucessional, motivo e uso do solo das áreas desmatadas. Os resultados indicaram que houve grande redução (58\%) no número de desmatamento entre 2007 e 2015. No entanto, o corte seletivo de Araucaria angustifolia (Bertol.) Kuntze ainda foi predominante com 62,07\% do número total de ocorrências. Verificou-se também que 71,46\% dos
\end{abstract}


desmatamentos atingiram o estágio médio de regeneração da floresta. Na maioria dos casos (33\%), o motivo do desmatamento foi para fins comerciais. A lei de proteção ao Bioma Mata Atlântica, aliado ao trabalho de fiscalização, contribuiu para a redução do número de desmatamentos e do corte de araucárias. Porém, avanços ainda são necessários, em especial na recuperação das áreas desmatadas, pois apenas $28 \%$ das áreas desmatadas foram efetivamente restauradas.

Palavras-Chave: Bioma Mata Atlântica; Fiscalização; Infrações Ambientais.

\section{INTRODUCTION}

The Atlantic Forest is composed by a set of forest formations (Forests: Dense Ombrophilous, Mixed Ombrophilous, Semideciduous Seasonal, Deciduous Seasonal and Open Ombrophilous) and associated ecosystems such as restingas, mangroves and altitude fields (Brasil, 2015). In Santa Catarina (SC), the phytoecological region of the Mixed Ombrophilous Forest (MOF) originally covered the largest part of the State surface, about $45 \%$ (Montagna et al., 2012); however, there are currently only $24.4 \%$ of its original area (Vibrans et al., 2013), a reflection of a strong policy of forest exploitation that began in the 1950s and 1960s (Hoff and Simioni, 2004).

The deforestation of the Atlantic Forest has been causing severe fragmentation and habitat reduction, as well as loss of biodiversity, especially of species endemic to the biome (Myers et al., 2000; Pinto et al., 2006). In the Planalto Serrano (Serrano Plateau) region of Santa Catarina alone, more than 500 criminal cases associated with MOF deforestation in the last nine years (Santa Catarina, 2016) were instituted. These deforestations were caused by several reasons of property use, especially for wood sale, an alternative land use (Santa Catarina, 2016).

The Brazilian Federal Constitution of 1988 recognized the relevance of this biome in paragraph 4 of section 225, where it treats the Biome as national patrimony, and determines that its use must be, in accordance with the law, under conditions that ensure the preservation of the environment, including the use of natural resources (Brasil, 1988). In order to regulate this device, Law No. 11,428 was issued on December 22, 2006, which deals with the use and protection of native vegetation of the Atlantic Forest Biome (Brasil, 2006).

In view of the concurrent competence among the entities of the federation, in the State of Santa Catarina, attention is paid to the service regarding environmental occurrences given by the Environmental Military Police - PMA. Since its creation in 1990, the PMA has been recognized by society due to its importance in the fight for environmental protection, since the Command of Environmental Military Policing represents to Santa Catarina's ostensible police a milestone to act in the defense of the environment, internalizing its constitutional mission (Venâncio, 2015).

The PMA has a hierarchical structure in commands with specific missions, and among them is the Environmental Policing Command - CPMA, containing two Battalions (BPMA), being the $1^{\text {st }}$ Battalion based in Florianópolis, distributed in four Companies (Cia PMA), and the $2^{\text {nd }}$ Battalion, based in Chapecó, with three Companies.

In the municipality of Lages, SC, an Environmental Military Police Company is headquartered, which covers a circumscribed area of 64 municipalities. The geographic characterization extends from the Planalto Serrano to the Midwest of Santa Catarina, whose body has as its attribution to exercise the ostensible police related to: the guarding and inspection of forests and springs and the protection of the environment, in accordance with the terms of section 107, subsection I, clauses "d" and "g", of the State Constitution of 1989 (Santa Catarina, 1989). Therefore, it is the responsibility of the PMA to identify the authorship and quantify the damage, for applying the current legislation on deforestation of forest areas in the region. However, as evidenced by the number of occurrences registered by the Environmental Military Police, we have a strong indication of the non-compliance with the protection norms of natural resources. This scenario may be observed in relation to the prohibition of cutting araucaria. Although there is a prohibitive forecast, that is ignored by the rural landowner who has other economic and subsistence needs, far from the preservation of the species.

Revista Árvore. 2018;42(2):e420206 
Thus, the objectives of this study were: 1) to analyze the history of deforestation in the Planalto Serrano of the State of Santa Catarina, whose forest cover is characterized by the Mixed Ombrophilous Forest; 2) to verify the effectiveness of the application of Law No. 11,428/06 in the occurrence of deforestation, and $3)$ to identify the reasons for deforestation.

\section{MATERIALAND METHODS}

\subsection{Study Site}

This study included information from 24 municipalities in the Serrana Region of Santa Catarina, located in the coverage area of the PMA ( $\left(1^{\text {st }} \mathrm{Cia}-2^{\text {nd }}\right.$ BPMA) of the same region (Figure 1).
The forest cover in the Santa Catarina Serrana region is formed by the Mixed Ombrophilous Forest, characterized by a heterogeneous formation of vegetation with primitive genera such as Drimys, Araucaria (Australasian) and Podocarpus (AfroAsian), and it may be subdivided according to the altitude and the proximity of the water course (Higuchi et al., 2013). Four MOF formations are identified: Alluvial - on old terraces associated with the river system; Sub-montane - constituting disjunctions at altitudes below $400 \mathrm{~m}$; Montane - located approximately between 400 and 1,000 m of altitude; and High Montane comprising altitudes above $1,000 \mathrm{~m}$ (IBGE, 2012). The Planalto Serrano is located in the central portion of the state, to the south and more to the east than to

\section{Circumscription 1st Cia / 2nd BPMA}

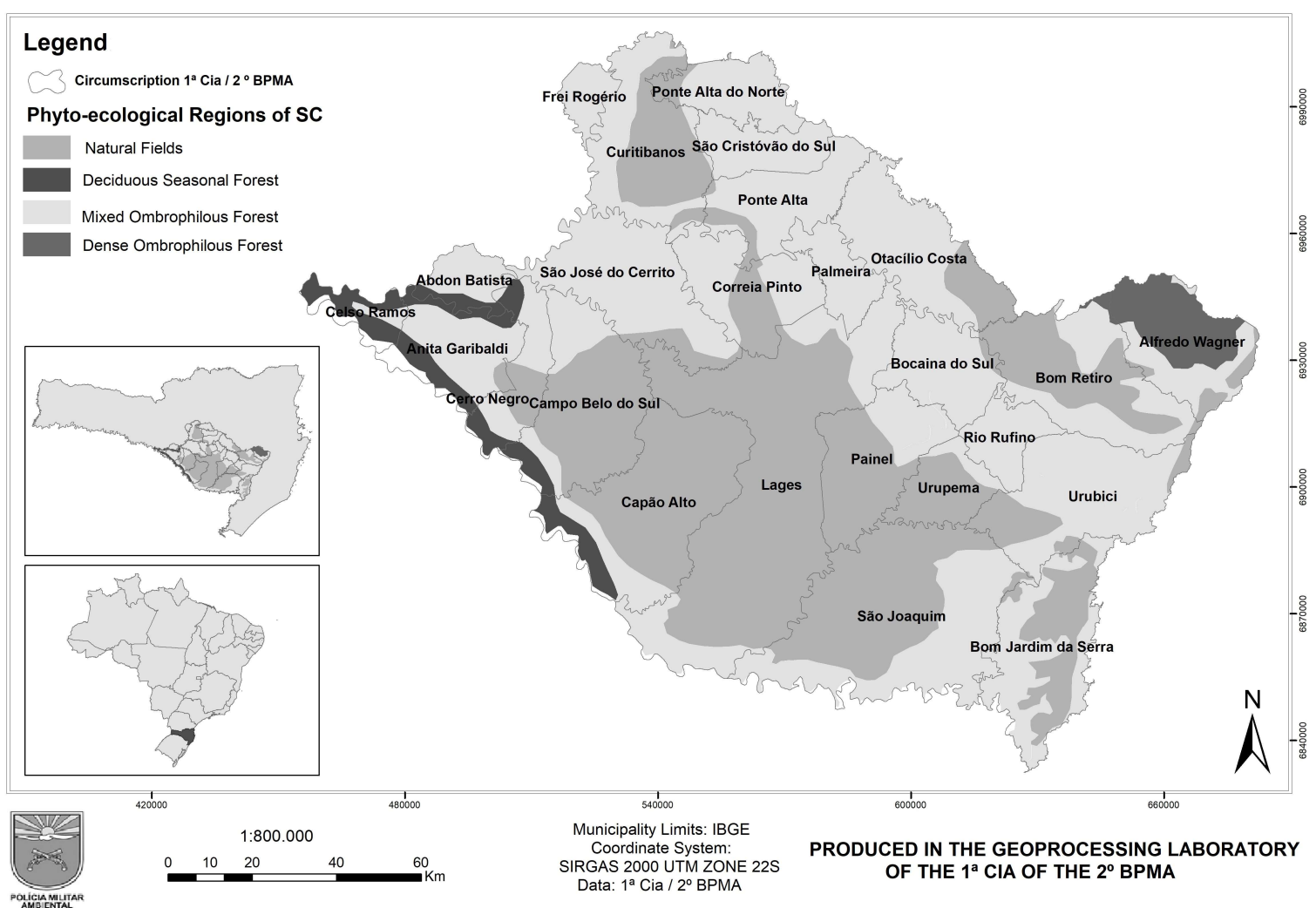

Figure 1 - Location of the 24 municipalities of the Planalto Serrano of Santa Catarina State. Figura 1 - Localização dos 24 municipios do Planalto Serrano do estado de Santa Catarina. 
the west, it has relief with great variation, occurring from mountainous to smooth wavy relief, with altitudes oscillating between 700 and 1,800 m above sea level and with an altitudinal gradient declining in the EastWest direction.

The municipalities in which this research was carried out are part of the Macroregion of Serra Catarinense, with an average altitude of 740 meters above sea level, with a minimum of 716 meters registered in Abdon Batista and a maximum of 1,353 meters in São Joaquim. The vegetation of this region is formed by a mosaic of fields and MOF Montane and High Montane, adapted to a rigorous winter with occurrence of snow and frost (Higuchi et al., 2013). The climate is humid subtropical with welldistributed rains throughout the year and rigorous winter with temperatures below $0^{\circ} \mathrm{C}$ (IBGE, 2012).

\subsection{Type of study, Sampling and Data collection}

This study was carried out based on the analysis of criminal cases obtained from the Subunit of the Military Environmental Police, headquartered in Lages, SC-Brazil.

The documentary research was based on the analysis of the 1,369 criminal procedures instituted by the PMA, generated from 2007 to 2015, of which, after the enactment of Law 11,428/06 (Brasil, 2006), 543 were about deforestation, all of which were selected for the study. In each case regarding deforestation, the following data were extracted: date, number of occurrences per year and municipality, type of land use of the deforestation areas, reason, deforested area, area recovery and successional stage. The occurrences were also stratified according to types of deforestation (clearcutting, selective cutting, soil scraping). This results from the characterization of the criminal offense, with the description of the offense, extent of the damage and, consequently, it reflects in the form of committed infraction and in the reparation of the damage.

It is also worth noting that in compliance with the requirement of the criminal type set forth in section 38-A of the Law on Environmental Crimes (Law No. $9,605 / 98)$, introduced by Law No. $11,428 / 06$, there is a need to characterize the successional stage of the damaged or destroyed vegetation for the enforcement of criminal law. Thus, in order to characterize the successional stage of the vegetation, the PMA uses CONAMA Resolutions 10/1993 and 01/1994, validated by Resolution No. 388/2007 (CONAMA, 1993, 1994; Brasil, 2007) (Vibrans et al., 2013).

\subsection{Data analysis}

The information extracted from each criminal process was tabulated in Excel(C) spreadsheets, with a basic descriptive analysis of the data (sum and percentage).

The geographic coordinates in SIRGAS2000 (Universal Transverse Mercator - UTM) were plotted in the software ArcGIS Desktop 10.5 to generate thematic maps, spatializing the occurrences of deforestation in the circumscription area of the PMA Subunit of Lages, $\mathrm{SC}$. The images used in the maps were from the Aerophotographic Survey of the State of Santa Catarina (SDS, 2013).

Pearson's linear correlation coefficient (r) was used to assess the association between the variables size of the deforested area and the number of infractions over the nine years of study. The variation of data regarding the number of infractions over time and among municipalities was evaluated by the Student's t-test. The analyses were performed in the software Past (Hammer et al., 2001).

\section{RESULTS}

\subsection{Temporal and spatial distribution of deforestation}

Between December 2006 and December 2015 the PMA attended to 1,369 occurrences of various natures, of which 543 (39.66\%) were from deforestation. During the period, there was a decrease in the number of deforestation occurrences, with a reduction of $58 \%$ of cases in 2015 compared to the first year (2007) after

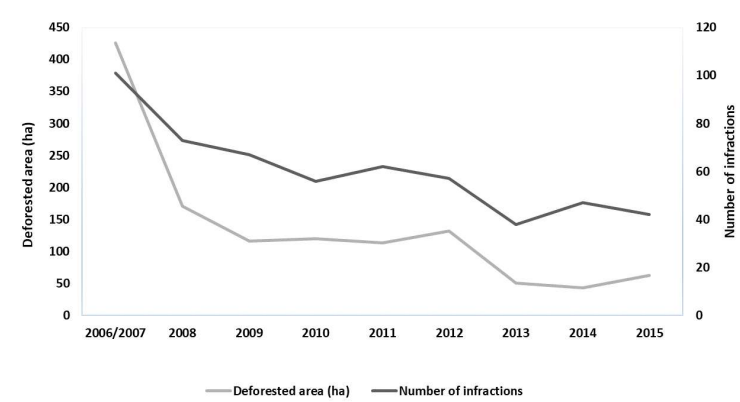

Figure 2 - Number of criminal infractions and size of the deforested area between 2006 and 2015 in the Planalto Serrano of Santa Catarina State.

Figura 2-Número de infrações penais e tamanho da área desmatada entre 2006 e 2015 no PlanaltoSerrana do estado de Santa Catarina.

Revista Árvore. 2018;42(2):e420206 
Total Occurrences of Flora

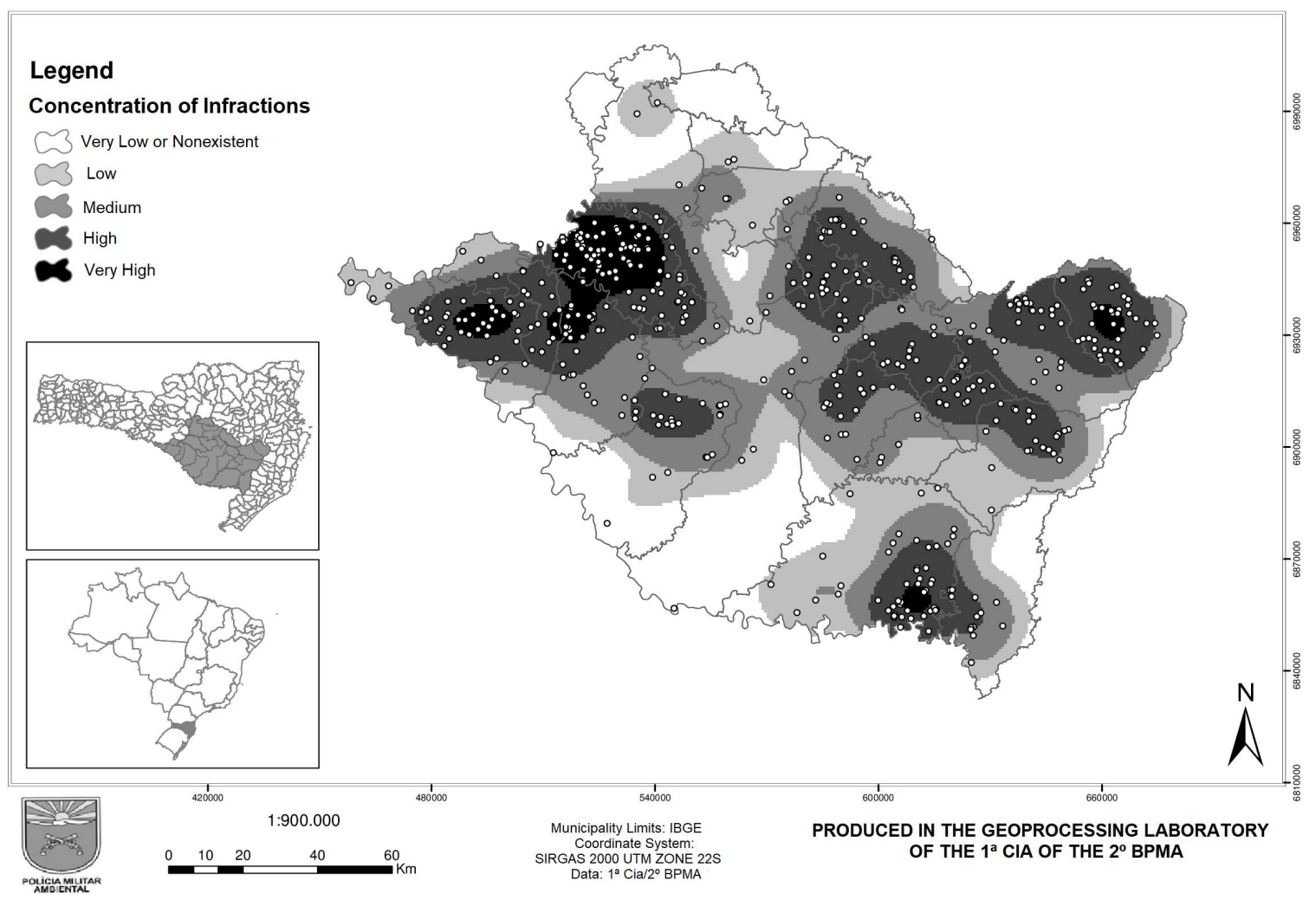

Figure 3 - Map with areas of the highest number of occurrences of deforestation in the Planato Serrano in the state of Santa Catarina, between January 2007 and December 2015.

Figura 3 - Mapa com áreas de maior ocorrência de desmatamento no Planalto Serrano do estado de Santa Catarina, entre janeiro de 2007 e dezembro de 2015.

the enactment of the Atlantic Forest Biome Law. The size of the deforested area was correlated with the number of infractions registered ( $r=0.94, p=0.0002)$, with a reduction in the size of the deforested area over these nine years (Figure 2), with a significant and positive correlation, i.e., as the deforested area decreases, there is also a reduction in the number of infractions.

The number of occurrences due to deforestation showed significant variations among the municipalities of the study ( $t=4.6, p=<0.001)$ and in the time span $(t=9.5, p=<0.001)$. The deforestation was concentrated in areas where forest cover was still preserved, especially in the municipalities of São José do Cerrito with a total of 113 infractions (20.81\%), São Joaquim with 52 (9.58\%) and Alfredo Wagner with $44(8.10 \%)$ registers of deforestation attended to by the PMA (Figure 3). The forest affected by deforestation in these municipalities was the middle stage of regeneration, whose tree size had a greater economic interest. Few cases of native vegetation cutting were registered within the municipalities of Abdon Batista (0.55\%), Celso Ramos $(1.10 \%)$ and Urupema $(0.92 \%)$. Lages registered 27 occurrences $(4.97 \%$ of the total).

The municipality of São José do Cerrito presented an increase in the number of deforestation in 2008 with 16 occurrences, returning to that index in 2014. São Joaquim, in its turn, presented 11 occurrences in 2010 , and the lowest index in 2012, with only two occurrences. The municipality of Anita Garibaldi had the highest number of occurrences in 2007 ( 11 occurrences), however, 
Table 1 - Number of criminal infractions between 2006 and 2015 in 24 municipalities of the Planalto Serrano of Santa Catarina State.

Tabela 1 - Número de infrações penais entre 2006 e 2015 em 24 municípios do Planalto Serrano do estado de Santa.

\begin{tabular}{|c|c|c|c|c|c|c|c|c|c|c|}
\hline Municipality & $2006 / 2007$ & 2008 & 2009 & 2010 & 2011 & 2012 & 2013 & 2014 & 2015 & $\begin{array}{l}\text { Grand } \\
\text { Total }\end{array}$ \\
\hline Abdon Batista & & 1 & & 1 & & & & 1 & & 3 \\
\hline Alfredo Wagner & 7 & 3 & 2 & 5 & 7 & 9 & 1 & 6 & 4 & 44 \\
\hline Anita Garibaldi & 11 & 7 & 5 & 4 & 3 & 8 & 2 & & 2 & 42 \\
\hline Bocaina do Sul & 5 & 1 & 2 & 1 & 5 & & 2 & 1 & 1 & 18 \\
\hline Bom Jardim da Serra & & 1 & 2 & 1 & 1 & 2 & 4 & & & 11 \\
\hline Bom Retiro & 6 & 4 & 4 & 3 & 8 & 5 & 3 & 1 & 1 & 35 \\
\hline Campo Belo do Sul & 4 & 9 & 4 & 3 & 2 & & & 2 & 8 & 32 \\
\hline Capão Alto & 8 & 5 & & 2 & 3 & 5 & 1 & & & 24 \\
\hline Celso Ramos & 2 & & 1 & 1 & & 1 & & & 1 & 6 \\
\hline Cerro Negro & 4 & 5 & 1 & 1 & 3 & & & & 5 & 19 \\
\hline Correia Pinto & 3 & & 1 & & & & & & & 4 \\
\hline Curitibanos & 3 & & & & & & & & & 3 \\
\hline Lages & 5 & 4 & 3 & 3 & 4 & 2 & 2 & 2 & 2 & 27 \\
\hline Otacílio Costa & 3 & 4 & 6 & 1 & 2 & 5 & & & & 21 \\
\hline Painel & 2 & 1 & 1 & 1 & 1 & 3 & 3 & 2 & 2 & 16 \\
\hline Palmeira & 6 & 3 & 3 & & 4 & & & 1 & & 17 \\
\hline Ponte Alta & 5 & 1 & & & & & & & & 6 \\
\hline Ponte Alta do Norte & 1 & & & & & & & & & 1 \\
\hline Rio Rufino & 6 & 3 & 7 & 2 & 1 & & & 2 & & 21 \\
\hline São Cristóvão do Sul & 2 & & & & & & & & & 2 \\
\hline São Joaquim & 4 & 3 & 9 & 11 & 6 & 2 & 6 & 7 & 4 & 52 \\
\hline São José do Cerrito & 12 & 16 & 14 & 15 & 9 & 13 & 9 & 16 & 9 & 113 \\
\hline Urubici & 2 & 2 & 2 & & 2 & 2 & 4 & 4 & 3 & 21 \\
\hline Urupema & & & & 1 & 1 & & 1 & 2 & & 5 \\
\hline Grand Total & 101 & 73 & 67 & 56 & 62 & 57 & 38 & 47 & 42 & 543 \\
\hline
\end{tabular}

in 2014 no case of deforestation was registered. The municipality of Alfredo Wagner presented the highest number of occurrences in 2012, with nine registered deforestation cases and the lowest index was the following year (2013), with only one registered occurrence (see Table 1 of the supplementary material).

\subsection{Types and reasons for deforestation}

The selective cutting of Araucaria angustifolia presented a higher percentage, reaching $62.07 \%$ of occurrences, followed by clearcutting $(27.80 \%)$ and soil scraping $(9.95 \%)$.

The reasons for deforestation were varied, however, the use of wood for commercial purposes was predominant in relation to the others with $33 \%$ (177 occurrences), followed by the use of the land for agriculture with 24\% (130 occurrences) and use in the property (building houses, renovations, etc.) with $23 \%$ (125 occurrences). When comparing deforestation among municipalities, São José do Cerrito had 58 occurrences of deforestation for commercial purposes, followed by São Joaquim with 15 and Campo Belo do Sul with 14 occurrences (Figure 4).

\subsection{Successional stage of the suppressed vegetation}

Data from deforestation infractions stratified by successional stages showed that most of the occurrences reached the middle regeneration stage $(71.46 \%)$. From the total of analyzed processes, $15.47 \%$ (84) did not present characterization of the vegetation in the registers. The initial stage presented a high percentage (12.34\%), while the vegetation in the advanced stage was suppressed in only four cases $(0.73 \%)$ of the total.

Among the municipalities, the secondary vegetation in the middle stage of deforested regeneration occurred mainly in São José do Cerrito with 84 occurrences, followed by São Joaquim with 46, Alfredo Wagner with 31 and Campo Belo do Sul with 27 processes, whereas the occurrences in the advanced stage were registered in Anita Garibaldi (two occurrences), Lages and Alfredo Wagner (both with one case).

Revista Árvore. 2018;42(2):e420206 


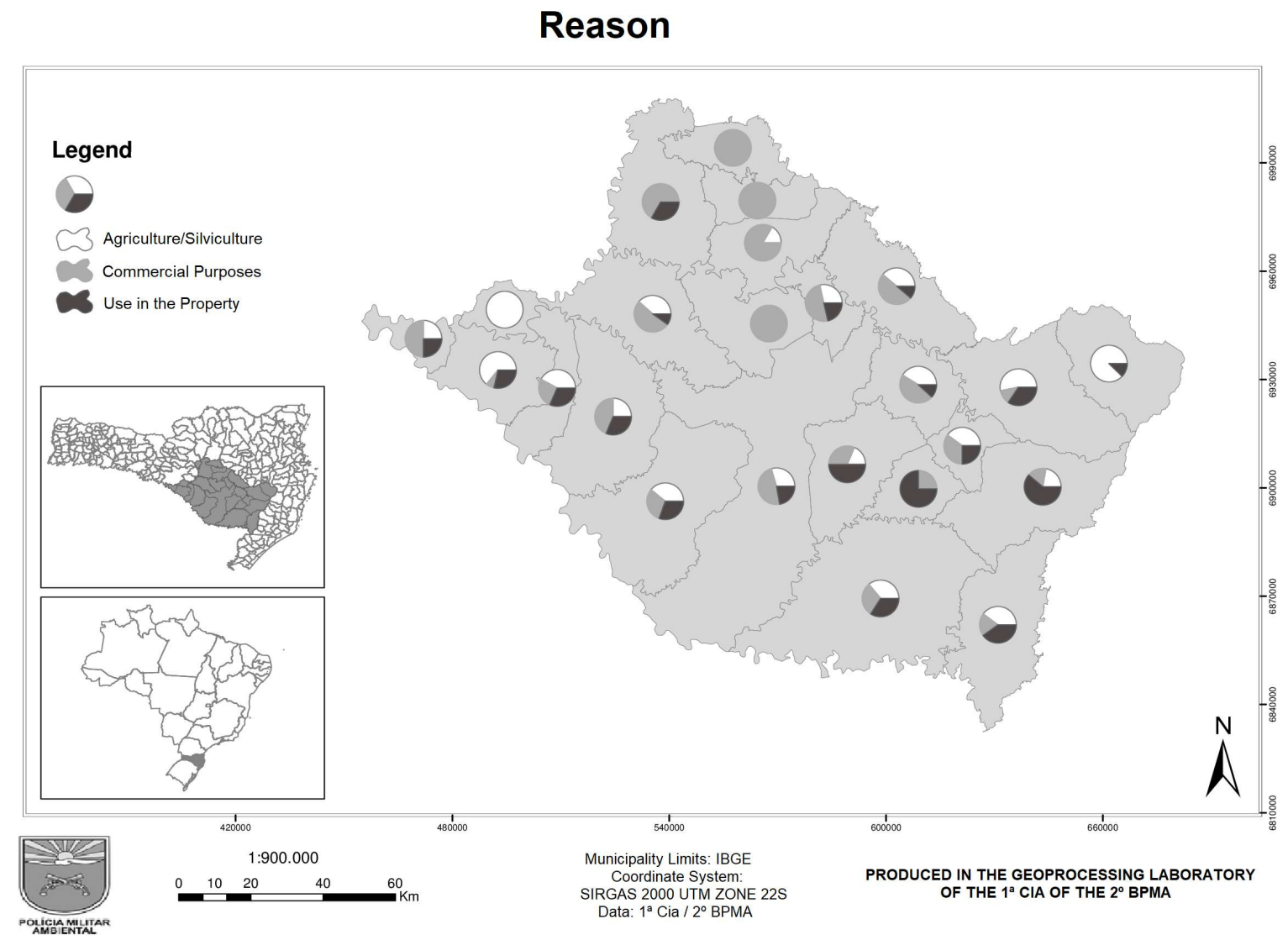

Figure 4 - Percentage of the reasons for deforestation by municipality of the Planalto Serrano region in the state of Santa Catarina, between 2006 and 2015. (Source: Santa Catarina, 2016). The corresponding municipalities are shown in Figure 1.

Figura 4-Percentual acerca dos motivos de desmatamentos por municipio da região serrana de Santa Catarina, entre 2006 a 2015. (Fonte: Santa Catarina, 2016).

From the definition of the successional stage of the deforested forest, it was defined the type of criminal infraction imputed to the offender. The data show that damage to forest in the middle or advanced stages of regeneration was predominant $(71.46 \%$, or 419 occurrences). On the other hand, the infraction characterized by preventing or hindering regeneration in the initial stage of regeneration (according to section 48 of Law No. 9,605/98) had a 13.08 ( 71 occurrences) damage percentage, followed by the suppression of native vegetation characterized by forest destruction with $9.76 \%$ (53 occurrences). As a consequence of the responsibility for deforestation, in addition to other impositions provided by law, there is an obligation to repair the damage. The data showed that between 2006 and 2015 there were 1,234.47ha of degraded area by deforestation, in which São José do Cerrito had the largest deforested area (327.70ha), followed by Otacílio Costa (105.42ha) and Anita Garibaldi (96.13ha). Of the $1,234.47$ ha, only $28 \%$ of the total area was recovered (351.33ha) and $\%$ (24.76ha) partially recovered. Sixteen percent (191.49ha) of the deforestation was not recovered and $54 \%$ (666.89ha) of the processes had no information regarding recovery, since the processes were not completed until the end of this study.

\section{DISCUSSION}

\subsection{Temporal and spatial distribution of deforestation}

The results showed a worrying reality regarding deforestation in the Serrana region of Santa Catarina, 
especially in relation to the size of the deforested area in the last nine years. Although the Atlantic Forest Biome Law deals with the use and protection of the native vegetation of the biome, it was not enough to completely cease the deforestation occurring annually in the region. Thus, effective control and inspection are needed as the foundation of any forest conservation strategy (Tabarelli et al., 2005).

At the beginning of the enactment of Law No. $11,428 / 06$, between 2006 and 2008, there was a high number of deforestation occurrences (average of 87 occurrences/year). However, in the following years (2009 to 2015), there was a reduction in infractions (average of 52.71) and a greater decrease in the last two years (47 occurrences in 2014 and 42 infractions in 2015). Law No. 11,428/06 created a criminal type and added section 38-A, in Law No. 9,605/98, with a penalty of detention, from one to three years, or a fine, or both penalties cumulatively. In other words, it became more rigid the responsibility for the offender who ventures to carry out deforestation without authorization from the competent environmental agency, which contributed to the reduction of deforestation in the region of this study.

In addition to the approval of the Law, inspection was more effective during this period. The work developed by the PMA in the Planalto Serrano of Santa Catarina, conjunctly with the technology available in the compilation and analysis of the data, contributed to the reduction of deforestation in the region. The use of software of geoprocessing of information, which helped in the spatialization of occurrences, made it possible to see in a systemic way the evolution and the sites with the highest concentration of deforestation and analysis of land use predominance in the described region. The spatialization of the data from this study showed that the number of deforestation occurrence differed among the municipalities of the Santa Catarina Plateau, making possible the future direction of the efforts to combat deforestation in the areas with the highest number of occurrences.

Recently, the SOS Mata Atlântica Foundation and INPE - National Institute of Space Research, published the Atlas of the Atlantic Forest Remains, which describes the study carried out on the regeneration of the Atlantic forest in Brazil, and the State of Santa Catarina has been outstanding for reducing deforestation rates since 2010 (Fundação SOS Mata Atlântica and INPE, 2017), corroborating the results of this study on the decrease in the number of deforestation cases in the Araucaria forest. However, it is worth mentioning that this result may also be a reflection of the progressive reduction of the forest in the region over the years, i.e., there is a reduction of deforestation because there was a reduction of forest to be deforested, a hypothesis not tested in this study.

Figure 4 shows the locations with the highest number of occurrences of deforestation in the region, forming six darker areas representing the highest concentrations of occurrences. On the other hand, the light areas have a low number of infractions (Figure 4).

\subsection{Types and reasons for deforestation}

The selective cutting of Araucaria angustifolia was the most representative in the municipalities of the study, except in Alfredo Wagner and Bom Retiro; both municipalities impacted the forest with clearcutting and scraping of soil with the use of a bulldozer blade. The main reason that led to the selective cutting of native trees was the commercialization of wood, which reached $33 \%$ of occurrences, indicating that rural landowners still use forest resources as a source of income. It is possible to understand this assertion of the socio-economic evolution of the region, historically, in the sense of maintaining the economy with an extractive model only, as evidenced by the research on the economic model of the region. Lages, specifically up to the peak of the timber cycle, had not invested in long-term economic alternatives, maintaining a predatory and primitive extractive model (Hoffand Simioni, 2004), which is reflected even today in the rural community.

The municipalities of the Serrana Macroregion have low state GDP, which represents only $4.8 \%$ of the economic movement in the state of Santa Catarina (SEBRAE, 2013). In this region, economic pressure is one of the drivers of land use change. The low value of land covered by native forests, as a consequence of the restrictions on the possibility of use of their resources, strongly contributes to the replacement of forested areas with other uses (Siminski and Fantini, 2010).

The other reasons for deforestation were the use of the soil for agriculture, followed by the use of wood in the property, silviculture and pasture. The burning

Revista Árvore. 2018;42(2):e420206

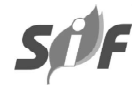


and cutting of tree vegetation for the expansion of grazing area for livestock feeding has also been a common practice in the Santa Catarina plateau, as well as the selective extraction of tree species for use in the property, such as firewood, wooden posts or boards, directly contributing to the reduction of the remains of the MOF, (Klauberg et al., 2010).

Deforestation for pasture cultivation for cattle accounted for $8 \%$ of occurrences. MOF fragments from the region are often used as grazing areas for cattle, raised extensively, especially in winter, when pastures have low biomass. In addition, they are also used by cattle as shelter against extreme temperatures, both in winter and summer. Once inside the Araucaria fragment, the cattle feed on palatable leaves, fruits and seeds, trample the seedlings and compact the soil, hindering seed germination and seedling growth, hindering the natural regeneration of the forest (Sampaio and Guarino, 2007). Another situation found was the deforestation for the introduction of silviculture, which also occurred in $8 \%$ of the cases. The replacement of native forests by silvicultural monocultures, such as Araucaria, changes the structure of the original communities, reducing resources for fauna, drastically reducing biodiversity (Copatti and Daudt, 2009). In addition, Araucaria has a great capacity for dispersion and colonization of new environments, such as the native fields associated with the Araucaria Forest, because its seeds are easily carried by the wind, they tolerate a range of environmental factors and, when adults, they limit growth of other species (allelopathic effect), altering the availability of light and nutrients in the environment (Simberloff et al., 2010; Maltchik et al., 2013).

Decree No. 6,660/2008 (Brasil, 2008), which regulates provisions of the Law No. 11,428/06, prohibits the exploitation of species included in the Official List of Brazilian Flora Species Threatened with Extinction (Brasil, 2014), in this case the Araucaria angustifolia. Therefore, the rural landowner cannot make the commercialization and use of the wood in his or her property. The scarcity of financial resources and low productivity of the land are factors that have probably led rural landowners in the region to convert the native wood into a financial resource for family subsistence, according to the justifications described in the processes, not considering the consequences of this act. Clearcutting and soil scraping, registered mainly in Alfredo Wagner and Bom
Retiro, seem to be associated to land use for subsistence farming (onion planting), considering that the deforested areas were small. Such infractions require more complex recovery techniques, since in addition to the suppression of native vegetation, complete removal of the seed bank occurs, which is very damaging to a short-term recovery. During the degradation processes of deforestation, the soil undergoes profound modifications as far as its chemical, biological and structural compositions are concerned. The loss of organic matter is the main consequence of degradation, delaying the successional process of restoration (Reis et al., 2007).

Loss of habitat and fragmentation of forests due to deforestation either by selective cutting, clearcutting or by scraping the soil with the use of a bulldozer, for the various registered land uses, may limit the migration, species colonization and the persistence of several populations at these locations (Tabarelli et al., 2005). Furthermore, habitat loss and fragmentation influence the demographic parameters of mortality and birth rate of different species and, consequently, directly affect the structure and dynamics of the ecosystem (Viana and Pinheiro, 1998).

\subsection{Successional stage of the suppressed vegetation}

The characterization of the MOF successional stage is provided for in Law No. 11,428/06, both for use and for possible accountability. The remains in the middle stage of regeneration were the most affected by deforestation in the Serrana region of Santa Catarina, followed by the initial and advanced stages. These data may reflect the current state of conservation of the state's forests, where the average regeneration stage still predominates with geographic distribution throughout the region, despite the strong exploitation in the timber period of the 1950s and 1960s (Hoff and Simioni, 2004).

It is estimated that the remains of the MOF, in the initial or even advanced stages, do not represent more than $0.7 \%$ of the original area (Mattos et al., 2010). The low number of deforestation cases registered in the initial stages does not mean that these areas have been preserved; however, it does reflect the existence of few areas at this stage of conservation. On the other hand, the high number of occurrences of deforestation in forests with middle regeneration stages results from the predominance of this type of forest cover in the studied municipalities. In the State of Santa Catarina,

Revista Árvore. 2018;42(2):e420206 
studies on the successional stage of vegetation remains are still incipient. The only Floristic and Forest inventory of Santa Catarina (Vibrans et al., 2013) contributed with the methodology for its characterization, however, it did not estimate the remaining vegetation cover area stratified by successional stages in the State. Nonetheless, their information is essential for the analysis of the different successional stages of forest remains.

The type of environmental crime committed by the offender is defined based on the successional stage of the native forest affected by deforestation. Hence, the PMA defines the successional stages using the methodology provided in CONAMA Resolutions No. 10/1993, 04/1994 and 388/2007 (Vibrans et al., 2013). Thus, the characterization of the successional stage has implications for the definition of criminal action, the possibilities of land use and, consequently, the economy and environmental policy (Siminski et al., 2013). Currently the PMA has equipment (sliding T bevel, electronic tape measure, among others), and its police officers have the capacity to evaluate fragments of forest in order to characterize the successional stage of the vegetation, fulfilling the requirements of the CONAMA Resolutions mentioned above. Therefore, it has a Standard Operating Procedure No. 11, as an institutional guideline regulating the practice of this characterization (Santa Catarina, 2011).

The legislation is clear regarding the obligation to repair the damage (paragraph 1 of section 14 of Law $6,938 / 81$ ) and this study showed that despite the register of occurrences and criminal cases, a large portion of deforested areas was not recovered, which requires the filing of a public civil lawsuit to impose this obligation. The justification of the rural landowners is that the recovery of the degraded areas is economically impracticable, making it difficult for the family to remain in the countryside. In these cases, the rural landowners are subject to a corresponding civil public lawsuit, promoted by the Public Prosecutor's Office, with the purpose of recovering the damage that has been caused.

Regarding the recovery of the degraded area, it depends on the severity of deforestation. In this sense, the techniques for recovery are also varied and analyzed in loco by a professional who will elaborate the Project of Recovery of Degraded or Disturbed Area (PRAD), as established by Normative Instructions No. 04/2011, 45/2013 and 11/2014 (IBAMA, 2011; ICMBIO, 2011;
PFE/IBAMA, 2013). By legal imposition, the offender must recover the damage caused, paying for the PRAD. One of the techniques recommended to the PRAD would be the recovery of degraded areas, potentiating natural processes of regeneration and succession (Zaú, 1998; Paludo et al., 2011).

The present study reinforces that, in addition to the application of environmental laws, inspection work and preventive actions of the military environmental police, it is necessary to promote a study of human needs, reconciling them with the conservation of the MOF of the Serrana Region of Santa Catarina. In addition, an important conservation strategy for the MOF is to increase knowledge about its biodiversity, which may be made feasible via basic and applied research.

\section{CONCLUSIONS}

The research showed that the concentration of deforestation is located in the municipality of São José do Cerrito, SC, where it exceeded $20 \%$ of the total registers. In the same sense, it was evidenced that the secondary vegetation in the middle stage of regeneration accounted for more than $70 \%$ of the occurrences of deforestation. The study presented relevant information on the type of deforestation, and the occurrences of the selective cutting of Araucaria exceeded $60 \%$ of the registers and, in addition, $33 \%$ of the flagrant use of wood was for commercial purposes. Furthermore, the research showed that less than $30 \%$ of the degraded areas were recovered, even though more than $50 \%$ of the deforestation processes were still to be tried. However, in addition to the figures, the spatialization of deforestation occurrences are essential to understand the dynamics of deforestation in the Serrana region of Santa Catarina. Based on the information extracted from the criminal procedures instituted by the PMA, public authorities, universities and civil entities may direct actions of research, environmental education, guidelines, prevention and inspection, with the aim of preserving the Atlantic Forest. The results may be used as an instrument by the inspection bodies to elaborate strategies and public policies to improve the indices of attendance of the occurrences and to increase the recovery of the degraded areas by deforestation. In addition, knowledge about the reasons that lead farmers to practice deforestation may also anticipate actions to cope with infractions. Thus, the formulation and application of Environmental Laws and the use

Revista Árvore. 2018;42(2):e420206

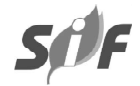


of strategies of environmental control, prevention or education may help reduce the indices of deforestation in the Serrana region of Santa Catarina.

\section{REFERENCES}

Brasil. Constituição. Constituição da República Federativa do Brasil. Brasília, DF: Diário Oficial da União; 1988.

Brasil. Leis e Decretos. Lei no 9.605, de 12 de fev. de 1998. Dispõe sobre as sanções penais e administrativas derivadas de condutas e atividades lesivas ao meio ambiente, e dá outras providências. Brasília, DF: Diário Oficial da União, 1998.

Brasil. Leis e Decretos. Lei ${ }^{\circ} 11.428$, de 22 de dez. de 2006. Dispõe sobre a utilização e proteção da vegetação nativa do Bioma Mata Atlântica, e dá outras providências. Brasília, DF: Diário Oficial da União, 2006.

Brasil. Leis e Decretos. Resolução CONAMA n ${ }^{\circ}$. 388, de 23 de fev. de 2007. Dispõe sobre a convalidação das resoluções que definem a vegetação primária e secundária nos estágios inicial, médio e avançado de regeneração da Mata Atlântica para fins do disposto no art. $4^{\circ}$ da Lei n. 11.428, de 22 de dez. de 2006. Brasília, DF: Diário Oficial da União, 2007.

Brasil. Leis e Decretos. Decreto $\mathrm{n}^{\circ}$ 6.660, de 21 de nov. de 2008. Regulamenta dispositivos da Lei no 11.428 , de 22 de dez. de 2006, que dispõe sobre a utilização e proteção da vegetação nativa do Bioma Mata Atlântica. Brasília, DF: Diário Oficial da União, 2008.

Brasil. Ministério do Meio Ambiente. Portaria $n^{\circ}$ 443, de 17 de dezembro de 2014. Reconhecer como espécies da flora brasileira ameaçadas de extinção aquelas constantes da "Lista Nacional Oficial de Espécies da Flora Ameaçadas de Extinção". Ministério do Meio Ambiente. Brasília, DF: Diário Oficial da União, Seção 1, no 245, quinta-feira, 18 de dez. de 2014.

Brasil. Ministério do Meio Ambiente. Mata Atlântica. Brasília, DF: Ministério do Meio Ambiente, 2015. [acessado em: 17 nov. 2016] Disponível em: http://www.mma.gov.br/biomas/ mata-atlantica.
Copatti CE, Daudt CR. Diversidade de artrópodes na serapilheira em fragmentos de mata nativa e Pinus elliottii (Engelm. Var elliottii). Ciência e Natura. 2009;31(1):95-113.

Fundação SOS Mata Atlântica \& Instituto Nacional de Pesquisas Espaciais - INPE. Atlas dos remanescentes florestais da Mata Atlântica e ecossistemas associados no período de 19852015. Fundação SOS Mata Atlântica/INPE; 2017.

Hammer Ø, Harper DAT, Ryan PD. Paleontological Statistics Software: Package for Education and Data Analysis. Palaeontologia Electronica, 2001;4(1):1-9.

Higuchi P, Silva AC, Almeida JÁ, Bortoluzzi RLC, Mantovani A, Ferreira TS. et al. Florística e estrutura do componente arbóreo e análise ambiental de um fragmento de Floresta Ombrófila Mista Alto-Montana no município de Painel, SC. Ciência Florestal. 2013;23(1):153-64.

Hoff DN, Simioni FJ. O setor de base florestal na serra catarinense. Lages: UNIPLAC; 2004.

Instituto Brasileiro do Meio Ambiente e dos Recursos Naturais Renováveis - IBAMA. Instrução Normativa $n^{\circ}$ 04/2011. Projetos de Recuperação de Áreas Degradadas - PRAD ou Áreas Alteradas. Brasília, DF: Diário Oficial da União, Seção 1, no 72, quinta-feira, 14 de abr. de 2011.

Instituto Brasileiro de Geografia e Estatística IBGE. Manuais técnicos em geociências. Divulga os procedimentos metodológicos utilizados nos estudos e pesquisas de geociências. Rio de Janeiro: IBGE; 2012.

Instituto Chico Mendes de Conservação da Biodiversidade - Instituto Chico Mendes.

ICMBIO. Instrução Normativa ICMBIO n ${ }^{\circ} 11$, de 11 de dez. de 2014. Estabelece procedimentos para elaboração, análise, aprovação e acompanhamento da execução do PRAD, para fins de cumprimento da legislação ambiental (ICMBIO, 2011). Brasília, DF: Diário Oficial da União, Seção 1, no 241, sexta-feira, 12 de dez. de 2014.

Klauberg C, Paludo GF, Bortoluzzi RLC, Mantovani $A$. Florística e estrutura de um fragmento de Floresta Ombrófila Mista no Planalto Catarinense. Biotemas. 2010;23(1):35-47. 
Maltchik L, Rolon AS, Cristina StenertIbere FC, Moreira MLFB. A invasão dos pinheiros: biodiversidade de áreas úmidas sob ameaça no Sul do Brasil. Ciência Hoje. 2013;302:37-40.

Mattos PP, Oliveira MF, Agustini AF, Braz EM, Rivera H, Oliveira YMA. et al. Aceleração do crescimento em diâmetro de espécies da Floresta Ombrófila Mista nos últimos 90 anos. Pesquisa Florestal Brasileira. 2010;30(64):319.

Myers N, Mittermeier RA, Mittermeier CG, Fonseca GAB, Kent J. Biodiversity hotspots for conservation priorities. Nature. 2000;403(6772):853-8.

Montagna, T, Ferreira DK, Steiner F, Silva FALS, Bittencourt R, Silva JZ. et al. A importância das unidades de conservação na manutenção da diversidade genética de araucária (Araucaria angustifolia) no Estado de Santa Catarina. Biodiversidade Brasileira. 2012;2(2):18-25.

Paludo GF, Mantovani A, Reis MS. Regeneration in a natural population of Araucaria angustifolia (Araucariaceae). Revista Árvore. 2011;35(5):1107-19.

PFE/IBAMA. Procuradoria Federal Especializada junto ao IBAMA - PFE/IBAMA. Orientação Jurídica Normativa n ${ }^{\circ}$ 45/2013/PFE/IBAMA (IBAMA, 2013), visando disciplinar qual legislação aplicável à elaboração do PRAD. [acessado em: 17 nov. 2016]. Disponível em: http://www.agu.gov.br/page/content/detail/id_conteudo/ 96663.

Pinto LP, Bedê L, Paese A, FonsecaM, Paglia A, Lamas I. Mata Atlântica Brasileira: os desafios para conservação da biodiversidade de um hotspot mundial. In: Rocha CFD, Bergallo HG, Sluys MV, Alves MAS. editores. Biologia da conservação: essências. São Carlos: RiMa; 2006. p.91-118.

Reis A, Tres DR, Scariot EC. Restauração na Floresta Ombrófila Mista através da sucessão natural. Pesquisa Florestal Brasileira. 2007(55)67-73.

Sampaio MB, Guarino ESG. Efeitos do pastoreio de bovinos na estrutura populacional de plantas em fragmentos de Floresta Ombrófila Mista. Revista Árvore. 2007;31(6):1035-46.

Santa Catarina. Constituição do Estado de Santa Catarina. Florianópolis, SC: Diário da Constituinte no. 039-A. 1989.
Santa Catarina. Polícia Militar Ambiental. Procedimento Operacional Padrão no 11/CTAF/ BPMA/2011. (Parâmetros para caracterização dos estágios sucessionais do Bioma Mata Atlântica. 2011.

Santa Catarina. Secretaria de Desenvolvimento Econômico Sustentável do Estado de Santa Catarina - SDS. Levantamento Aerofotogramétrico do Estado de Santa Catarina. Florianópolis: ENGEMAP, 2013. (Documento Digital).

Santa Catarina. Polícia Militar Ambiental. Dados fornecidos pela Polícia Militar Ambiental dos procedimentos instaurados na vigência da Lei ${ }^{\circ}$ $11.428 / 06$, entre 26 de dezembro de 2006 a 31 de dezembro de 2015, na subunidade em Lages, 2016.

SEBRAE/SC. Santa Catarina em Números: Macrorregião Serra Catarinense/Sebrae/SC. Florianópolis: SEBRAE; 2013.

Simberloff D, Nuñez MA, Ledgard NJ, Pauchard A, Richardson DM, Sarasola M et al. Spread and impact of introduced conifers in South America: lessons from other southern hemisphere regions. Austral Ecology. 2010;35(5):489-504.

Siminski A, Fantini AC. A Mata Atlântica cede lugar a outros usos da terra em Santa Catarina, Brasil.

Biotemas. 2010;23(2):51-9.

Siminski A, Fantini AC, Reis MS. Classificação da vegetação secundária em estágios de regeneração da Mata Atlântica em Santa Catarina. Ciência Florestal. 2013;23(3):369-78.

Tabarelli M, Pinto LP, Silva JMC, Hirota MM, Bedê LC. Desafios e oportunidades para a conservação da biodiversidade na Mata Atlântica brasileira. Megadiversidade. 2005;1(1):132-8.

Venâncio VR. Ordem Pública Ambiental: a atuação da polícia ostensiva na proteção do Meio Ambiente. Blumenau: Nova Letra; 2015.

Viana VM, Pinheiro L. Conservação da biodiversidade em fragmentos florestais. Série Técnica IPEF.

1998;12(32):25-42.

Vibrans AC, Sevegnani L, Gasper AL, Lingner DV.. Inventário florístico florestal de Santa Catarina: Floresta Ombrófila Mista. Blumenau: Edifurb; 2013. v.3. 